\title{
Molecular Detection of Hepatitis A Virus in Urban Sewage in Isfahan, Iran
}

\author{
Shima Najar (MSc) \\ Department of Microbiology, \\ Falavarjan Branch, Islamic Azad \\ University, Isfahan, Iran \\ Nafiseh Sadat Naghavi (PhD) \\ Department of Microbiology, \\ Falavarjan Branch, Islamic Azad \\ University, Isfahan, Iran \\ Corresponding author: Nafiseh \\ Sadat Naghavi \\ Tel: +983137420134 \\ Email:nafiseh_naghavy@yahoo.com \\ Address: Department of \\ Microbiology, Falavarjan Branch, \\ Islamic Azad University, Isfahan, \\ Iran \\ Received : 24 Jan 2018 \\ Revised: 26 Apr 2018 \\ Accepted: 25 Apr 2018
}

\begin{abstract}
Background and Objectives: Hepatitis A virus (HAV) enters sewage through the stool of infected patients and contaminates freshwater and seawater. The aim of present study was quantitative molecular detection of HAV in raw and treated urban sewage samples from Isfahan, center of Iran.

Material and methods: Sewage samples were collected from six urban treatment plants in cold and warm weather, between December 2016 and Jun 2017. Physicochemical indicators were measured immediately after sampling. Viral particles were isolated and concentrated by modified adsorption-elution method using $\mathrm{Al}^{3+}$-coated filters. Quantitative PCR was done for amplification of a fragment in the highly conserved 5' noncoding region of the HAV genome.

Results: Although the values of the indicators were lower in $67-83 \%$ of sewage samples in warm weather, no significant difference was detected between the physicochemical indicators of sewage samples. HAV was detected in three raw sewage samples collected in cold weather (copy number of 32590, 28400 and 14200 per $\mu \mathrm{l}$ ) and in one treated sewage sample (copy number of 6500 per $\mu \mathrm{l}$ ) collected in cold weather. Positive HAV sewage samples had been treated by activated sludge and aerated lagoon.

Conclusion: We detected high frequency of HAV in raw urban sewage samples from Isfahan, Iran. This highlights the importance of paying extra attention to irrigation of farms with raw sewage. Based on the results of this study and previous studies, it can be concluded that the activated sludge system may be more effective for elimination of enteric viruses, such as HAV.
\end{abstract}

Keywords: Hepatitis A virus, Sewage, Weather. 


\section{INTRODUCTION}

Human enteric viruses including hepatitis A virus (HAV) are largely reserved in municipal effluents $(1,2)$. Recently, indicator bacteria have been tested for sewage monitoring (3), but there is no standard protocol considering the use of viruses as indicators of water and sewage quality.

$\mathrm{HAV}$ is an enteric, non-enveloped single stranded RNA virus with a single serotype that can cause liver inflammation (hepatitis). The virus is mostly transmitted via the fecal-oral route (4). Hepatitis A (formerly known as infectious hepatitis) is an acute infectious disease of the liver (5). Public health protection is associated with virological monitoring of water and sewage using efficient methods. Reverse transcriptase-quantitative polymerase chain reaction (RT-qPCR) has been successfully used for quantification of enteric RNA viruses in environmental samples because of its high specificity and sensitivity (6-8). The application of RT-PCR for detection of enteric viruses in complex environmental samples such as sewage depends on the initial concentration and purification of virus particles from samples because of low virus count and presence of natural inhibitors of the amplification reaction. Different methods have been developed and proposed to overcome these problems (9-11). The aim of the present study was to isolate and concentrate HAV particles from raw and treated sewage samples in Isfahan (center of Iran) and enumeration of viral RNA in the samples by RT-qPCR.

\section{MATERIAL AND METHODS}

Twenty-four raw and treated sewage samples were collected from six urban treatment plants in Isfahan Province, Iran. The samples were collected in the cold and warm weather from December 2016 to Jun 2017. The study area and sampling sites are shown in figure 1 (12). Some characteristics of the sewage treatment systems from which the samples were obtained are shown in table 1. Physicochemical indicators of the samples including $\mathrm{pH}$, electrical conductivity (EC), turbidity, biological oxygen demand (BOD), chemical oxygen demand (COD), total suspended solids (TSS) and turbidity were measured immediately after sampling.
Differences in the mean values of the indicators were analyzed by analysis of variance (ANOVA).

All chemicals were purchased from Merck Chemical Company, Germany. Digital electrodes (Hanna Instruments, USA) were used for measurements of the values according to the manufacturer's instructions. Respirometery (3) was used for BOD analysis. First, $200 \mathrm{ml}$ of each sample along with $0.16 \mathrm{~g}$ nitrification inhibitor were poured in dark bottles. A bottle containing equal amount of distilled water was used as control. The bottles were capped [equipped with dissolved oxygen (DO) probes] and incubated in BOD analyzer apparatus (Hach Company, Germany) for five days at $20{ }^{\circ} \mathrm{C}$. BOD5 was calculated based on the following formula:

$$
\text { BOD5 } \mathrm{mg} \mathrm{L}^{-1}=(\mathrm{D} 1-\mathrm{D} 2) \div \mathrm{P}
$$

BOD5 $=$ BOD value from the 5-day test $(\mathrm{mg}$ $\left.\mathrm{L}^{-1}\right)$

D1 $=$ DO of the prepared sample immediately after preparation $\left(\mathrm{mg} \mathrm{L}^{-1}\right)$

$\mathrm{D} 2=\mathrm{DO}$ of the prepared sample after incubation $\left(\mathrm{mg} \mathrm{L}^{-1}\right)$

$\mathrm{P}=$ Decimal volumetric fraction of sample used

Electrometric method was used for COD analysis (3). Two $\mathrm{ml}$ of each sample were poured and mixed in vials containing $0.04 \mathrm{~mol}$ $\mathrm{L}^{-1} \mathrm{~K}_{2} \mathrm{Cr}_{2} \mathrm{O}_{7}, 80 \mathrm{~g} \mathrm{~L}^{-1} \mathrm{HgSO}_{4}$ and $6.6 \mathrm{~g} \mathrm{~L}^{-1}$ $\mathrm{Ag}_{2} \mathrm{SO}_{4}$ in sulfuric acid. The vials were placed in Hach DRB reactor for two hours at $150{ }^{\circ} \mathrm{C}$. The amount of COD $\left(\mathrm{mg} \mathrm{L}^{-1}\right)$ was calculated using Hach's easy-to-use spectrophotometer (Germany) by automatic wavelength selection in contrast to the blank containing two $\mathrm{ml}$ distilled water instead of sample.

Each sample was poured in dried weighted crucible and incubated at $105{ }^{\circ} \mathrm{C}$ for eight hours. The crucible was then placed in a desiccator containing silica gel for $20 \mathrm{~min}$ for humidity absorption. Total solids (TS, $\mathrm{mg} \mathrm{L}^{-1}$ ) was calculated as the difference of the end weight of crucible and the initial weight of dried crucible. Moreover, the amount of total dissolved solids (TDS, $\mathrm{mg} \mathrm{L}^{-1}$ ) was measured by the same protocol except the samples were filtered by Whatman no. 1 filter paper (GE Healthcare, UK) before initiation of the procedure. TSS $\left(\mathrm{mg} \mathrm{L}^{-1}\right)$ was calculated by subtracting TDS from TS (3). First, one L of 
each sewage sample was centrifuged at $4000 \mathrm{~g}$ for $30 \mathrm{~min}$ at $4{ }^{\circ} \mathrm{C}$. The supernatant was seperated and labeled as Supern. 1. The sediment was suspended in 5 volume of $0.2 \mathrm{M}$ glycine- $0.15 \mathrm{M} \mathrm{NaCl}$ ( $\mathrm{pH}$ 9.5), homogenized and centrifuged again, and its $\mathrm{pH}$ was adjusted to 7.2-7.5 (6). The supernatant was separated and labeled as Supern. 2. Viruses in the supernatants were concentrated by the modified adsorption-elution method described by Haramoto et al. (13). In the first stage, $5 \mathrm{ml}$ of $250 \mathrm{mM} \mathrm{AlCl}{ }_{3}$ were passed through $0.45 \mu \mathrm{m}$ HAWP04700 membrane filter in a vacuum filtration system (Millipore, USA) to obtain cation $\left(\mathrm{Al}^{3+}\right)$-coated filters. Subsequently, total volume of Supern. 1 and $500 \mathrm{ml}$ of Supern. 2 were passed through the filters. Then, the cations were washed by passing $200 \mathrm{ml}$ of 0.5 $\mathrm{mM} \mathrm{H} \mathrm{SO}_{4}$ through the membranes. Finally, viral particles were eluted with $10 \mathrm{ml}$ of $1 \mathrm{mM}$ $\mathrm{NaOH}$ and elutes were placed in vials containing $0.1 \mathrm{ml}$ of $50 \mathrm{mM} \mathrm{H}_{2} \mathrm{SO}_{4}$ and $0.1 \mathrm{ml}$ of $100 \mathrm{X}$ Tris-EDTA buffer $(\mathrm{pH}=8)$ to neutralize before ultraconcentration. Centriprep YM-50 ultrafiltration device (Millipore, USA) was used for ultraconcentration of viral particles according to the manufacturer's protocol to obtain final volume of approximately $700 \mu$ l. This step was done in the Eppendorf 5415R (Germany) centrifuge. The concentrated samples were then stored at $-80{ }^{\circ} \mathrm{C}$ until RNA extraction (13, 14). RNA was extracted using QIAamp®UltraSens ${ }^{\circledR}$ Virus kit (Qiagen, Germany). RNA Clean and Concentrator ${ }^{\mathrm{TM}_{-}}$-5 kit (Zymo research, USA) was used to remove DNA. Quality of the extracted RNA was controlled using 4200 TapeStation System (Agilent Technologies, USA). Next, cDNA was synthesized using RevertAid ${ }^{\mathrm{TM}}$ First Strand cDNA Synthesis kit (Thermo Fisher Scientific, USA). First, $15 \mu$ l of the extracted RNA was incubated with $2 \mu \mathrm{l}$ of random hexamer primer at $72{ }^{\circ} \mathrm{C}$ for 5 minutes. Then, $\mathrm{RT}$ process was performed in reaction mixture containing $10 \mathrm{X}$ reaction buffer $(8 \mu \mathrm{l}), 10 \mathrm{mM}$
dNTP mix $(4 \mu \mathrm{l})$, random hexamer primer $(2$ $\mu 1), \quad 40$ units $/ \mu \mathrm{l}$ RibolockTM ribonuclease inhibitor $(1 \mu \mathrm{l})$, and 200 units $/ \mu \mathrm{l} \mathrm{M}-\mathrm{MuLV}$ reverse transcriptase $(2 \mu \mathrm{l})$. The reaction temperature started at $42{ }^{\circ} \mathrm{C}$ for 1 hour and then continued at $75^{\circ} \mathrm{C}$ for 10 minutes.

The procedure was done for amplification of the regions spanning positions 66 to 95 and 227 to 262 in the highly conserved $5^{\prime}$ noncoding region of HAV using Green PCR Master Mix (Life Technologies, USA) and specific primers (14) in a Real-Time PCR system (Rotor Gene Corbet, Australia). The primers including HAV68 (F): 5'-TCA CCG CCG TTT GCC TAG-3' and HAV240 (R): 5'GGA GAG CCC TGG AAG AAA G-3', and the probe HAV150 (5'TTAATTCCTGCAGGTTCAGG-3') were used in the qPCR reaction (14). The primers and probe were constructed by Bioneer Co. (South Korea). The reaction mixture $(25 \mu \mathrm{l})$ was prepared by mixing $5 \mu \mathrm{l}$ of cDNA with 20 $\mu \mathrm{l}$ of reaction buffer containing $12.5 \mu \mathrm{l}$ of $2 \mathrm{X}$ TaqMan universal PCR master mix (Applied Biosystems, USA), $400 \mathrm{nM}$ of each primer, $250 \mathrm{nM}$ TaqMan probe and PCR grade water (Applied Biosystems, USA). PCR cycling conditions were as follows: initial denaturation at $94{ }^{\circ} \mathrm{C}$ for $2 \mathrm{~min}$, followed by 50 cycles at 94 ${ }^{\circ} \mathrm{C}$ for $15 \mathrm{sec}$ and at $60{ }^{\circ} \mathrm{C}$ for $1 \mathrm{~min}$. Internal amplification control and positive control of the kit were co-amplified with the target HAV sequence to eliminate false-negative results according to the manufacturer's (Primerdesign Ltd.,UK) instructions. Standard curve was plotted using positive control template of the kit for the $5^{\prime}$ non-coding region of HAV (Primerdesign Ltd., UK). The copy number was $2 \times 10^{5}$ per $\mu l$ in the positive control template, which was diluted to obtain two copies per $\mu$ l. RNAse/DNAse free water (Applied Biosystems, USA) was used in negative controls and lack of amplification of non-target cDNA confirmed the specificity of the primer-probe combinations for the target cDNA.

Table 1- Some characteristics of the sampling sewage treatment systems

\begin{tabular}{ccc}
\hline Sample no. & Treatment system & $\begin{array}{c}\text { Influent flow } \\
\left(\mathbf{m}^{3} \text { per day }\right)\end{array}$ \\
\hline 1 & Activated sludge & 14000 \\
2 & Activated sludge & 130000 \\
3 & Activated sludge & 100000 \\
4 & Activated sludge & 250000 \\
5 & Activated sludge & 60000 \\
6 & Aerated lagoon & 12000 \\
\hline
\end{tabular}


Figure 1- The study area and location of the sewage treatment plants from which the samples were obtained (12).

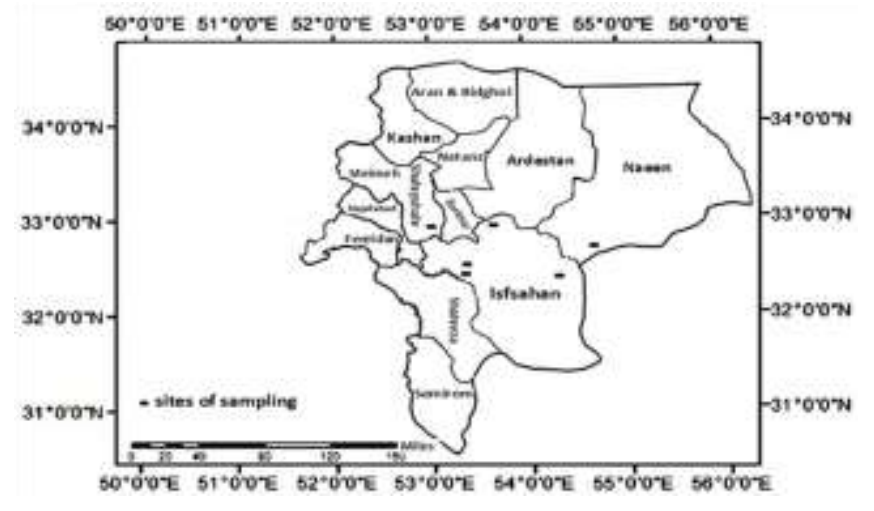

\section{RESULTS}

The level of BOD, COD, EC, TSS and turbidity decreased significantly after treatment of all raw sewage samples (Table 2). The physicochemical analysis of samples collected in the cold and warm weather showed no significant difference between raw and treated samples $(\mathrm{P}>0.05)$. However, the values of the indicators were lower in $67-83 \%$ of the sewage samples collected in warm weather. In addition, $\mathrm{pH}$ was slightly lower in $67 \%$ of samples collected in warm weather, but no significant difference was found between the $\mathrm{pH}$ of raw and treated samples collected in cold and warm weather $(\mathrm{P}>0.05)$.

Table 2a- Level of physicochemical indicators in six raw sewage samples collected in cold and warm weather

\begin{tabular}{cllllllllllll}
\hline Sample no. & \multicolumn{2}{c}{ BOD $\left(\mathbf{m g ~ L}^{-1}\right)$} & \multicolumn{2}{l}{ COD $\left(\mathbf{m g ~ L}^{-1}\right)$} & \multicolumn{2}{c}{ pH } & \multicolumn{2}{c}{ EC $\left(\mathbf{d S ~ m}^{-1}\right)$} & \multicolumn{2}{c}{ TSS $\left(\mathbf{m g ~ L ~}^{-1}\right)$} & \multicolumn{2}{c}{ Turbidity (Unit) } \\
\hline & Cold & Warm & Cold & Warm & Cold & Warm & Cold & Warm & Cold & Warm & Cold & Warm \\
$\mathbf{1}$ & $\mathbf{3 8 2}$ & $\mathbf{3 4 5}$ & $\mathbf{8 3 1}$ & $\mathbf{7 5 6}$ & $\mathbf{7 . 4 7}$ & $\mathbf{6 . 9 7}$ & $\mathbf{1 1 4 9}$ & $\mathbf{7 2 5}$ & $\mathbf{3 0 4}$ & $\mathbf{3 6 0}$ & $\mathbf{2 0 4}$ & $\mathbf{1 9 9}$ \\
$\mathbf{2}$ & $\mathbf{4 8 4}$ & $\mathbf{3 7 9}$ & $\mathbf{1 3 1 8}$ & $\mathbf{1 5 0 4}$ & $\mathbf{7 . 5 2}$ & $\mathbf{7 . 3 2}$ & $\mathbf{1 2 9 8}$ & $\mathbf{1 2 0 5}$ & $\mathbf{8 6 8}$ & $\mathbf{8 0 1}$ & $\mathbf{5 5 5}$ & $\mathbf{9 7 4}$ \\
$\mathbf{3}$ & $\mathbf{3 1 2}$ & $\mathbf{4 0 1}$ & $\mathbf{5 1 9}$ & $\mathbf{6 6 0}$ & $\mathbf{7 . 4 0}$ & $\mathbf{7 . 2 7}$ & $\mathbf{1 0 4 5}$ & $\mathbf{1 0 9 2}$ & $\mathbf{2 1 4}$ & $\mathbf{2 6 2}$ & $\mathbf{1 8 8}$ & $\mathbf{1 4 7}$ \\
$\mathbf{4}$ & $\mathbf{3 1 1}$ & $\mathbf{2 5 8}$ & $\mathbf{6 6 0}$ & $\mathbf{5 4 2}$ & $\mathbf{7 . 1 3}$ & $\mathbf{7 . 2 4}$ & $\mathbf{1 1 9 5}$ & $\mathbf{1 2 6 4}$ & $\mathbf{3 0 8}$ & $\mathbf{2 8 4}$ & $\mathbf{2 4 2}$ & $\mathbf{2 2 3}$ \\
$\mathbf{5}$ & $\mathbf{2 6 4}$ & $\mathbf{2 5 7}$ & $\mathbf{5 6 6}$ & $\mathbf{5 2 5}$ & $\mathbf{7 . 4 5}$ & $\mathbf{7 . 7 4}$ & $\mathbf{1 1 8 2}$ & $\mathbf{1 1 2 7}$ & $\mathbf{3 1 0}$ & $\mathbf{2 5 0}$ & $\mathbf{1 5 5}$ & $\mathbf{1 0 0}$ \\
$\mathbf{6}$ & $\mathbf{2 1 5}$ & $\mathbf{1 0 7}$ & $\mathbf{4 5 0}$ & $\mathbf{2 3 2}$ & $\mathbf{7 . 6 9}$ & $\mathbf{7 . 1 3}$ & $\mathbf{1 0 1 2}$ & $\mathbf{1 1 7 2}$ & $\mathbf{2 7 8}$ & $\mathbf{1 5 8}$ & $\mathbf{1 6 9}$ & $\mathbf{3 9 . 9}$ \\
\hline
\end{tabular}

Table 2b- Physicochemical characteristics of the six treated sewage samples collected in cold and warm weather

\begin{tabular}{|c|c|c|c|c|c|c|c|c|c|c|c|c|}
\hline \multirow[t]{2}{*}{ Sample no. } & \multicolumn{2}{|c|}{ BOD $\left(\mathrm{mg} \mathrm{L}^{-1}\right)$} & \multicolumn{2}{|c|}{$\operatorname{COD}\left(\mathrm{mg} \mathrm{L}^{-1}\right)$} & \multicolumn{2}{|c|}{ pH } & \multicolumn{2}{|c|}{$\mathrm{EC}\left(\mathrm{dS} \mathrm{m}^{-1}\right)$} & \multicolumn{2}{|c|}{$\operatorname{TSS}\left(\mathrm{mg} \mathrm{L}^{-1}\right)$} & \multicolumn{2}{|c|}{ Turbidity (Unit) } \\
\hline & Cold & Warm & Cold & Warm & Cold & Warm & Cold & Warm & Cold & Warm & Cold & Warm \\
\hline 1 & 24 & 23 & 54 & 45 & 7.09 & 7.07 & 11.60 & 8.13 & 28 & 26 & 5.96 & 2.57 \\
\hline 2 & 56 & 51 & 98 & 96 & 7.54 & 7.31 & 11.38 & 11.36 & 84 & 56 & 11.2 & 13.4 \\
\hline 4 & 98 & 92 & 298 & 226 & 7.18 & 6.87 & 11.60 & 12.08 & 86 & 126 & 39.2 & 39 \\
\hline 5 & 42 & 37 & 80 & 96 & 7.23 & 7.52 & 11.38 & 11.92 & 48 & 46 & 6.27 & 10.90 \\
\hline 6 & 69 & 48 & 137 & 110 & 7.42 & 7.29 & 9.01 & 7.17 & 62 & 26 & 20.04 & 18.90 \\
\hline
\end{tabular}

Figure 2- Standard curve and amplification plot for HAV quantification in different sewage samples

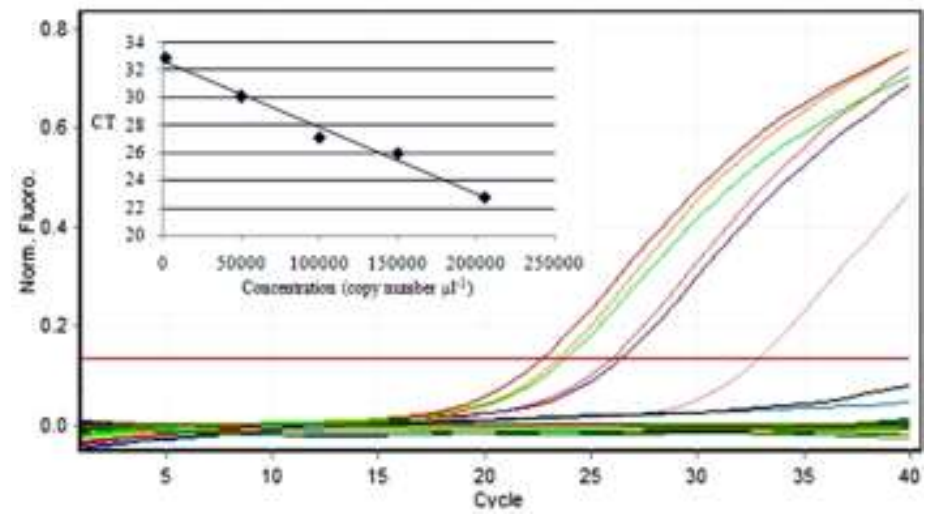


Figure 2 shows the results for quantitative detection of HAV in different samples.

The standard curve was obtained using different concentrations of the positive control. Samples with threshold cycle (CT) value of $\leq 33$ were defined as positive. A 218 nucleotides long fragment was amplified. As shown in figure 3 , HAV gene was found in 3 raw samples collected in cold weather from sampling sites no. 1 (14200 copy number $\mu l^{-1}$ ), no. 4 (32590 copy number $\left.\mu l^{-1}\right)$ and no. 6 (14200 copy number $\mu 1^{-1}$ ). Moreover, the virus was found in treated samples collected in cold weather from sampling site no. 6. The HAV gene was absent in all samples collected in warm weather.

Figure 2- Standard curve and amplification plot for HAV quantification in different sewage samples

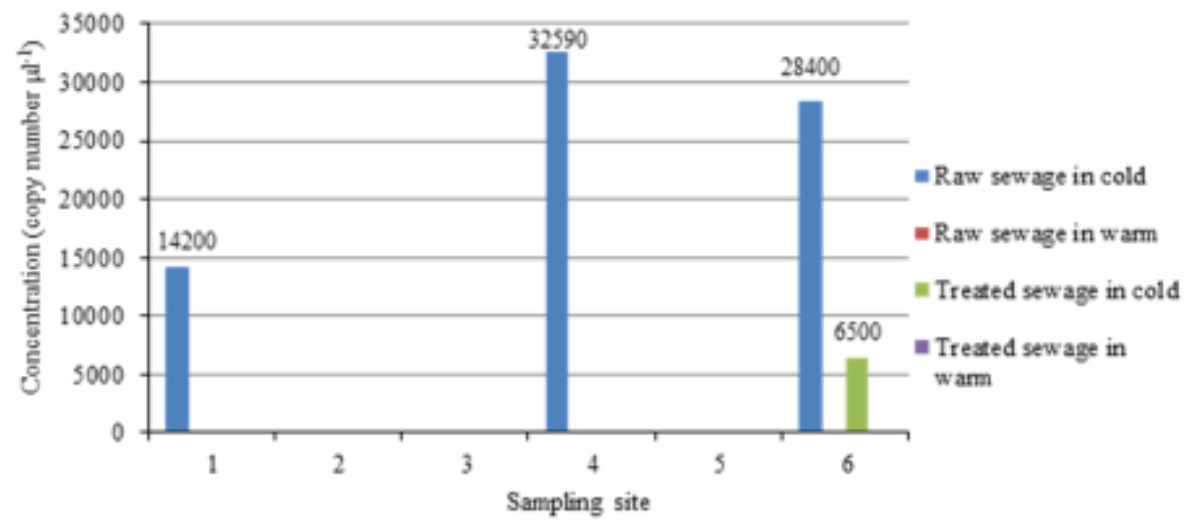

\section{DISCUSSION}

HAV infection is a major public health concern. About 1.4 million cases of HAV infection occur every year worldwide (15). $\mathrm{HAV}$ is endemic in most African, Asian, South American and Central American countries, whilst improved sanitation in most western countries have reduced the risk of HAV outbreaks $(16,17)$. The overall rate of HAV seropositivity has been reported to be $64 \%$ in Iran (18). Exposure to sewage has been associated with a slight increase in risk of subclinical hepatitis A disease (19). On the other hand, it has been reported that exposure to wastewater used for irrigation significantly increases the risk of HAV infection, especially among children less than 10 years of age (20). Considering the irrigation of farms with raw and treated sewage, the present study aimed to investigate the presence of HAV in urban sewage in Isfahan, Iran. The results of the study would be provided to the health authorities. Simple sample processing procedures consisting of initial separation of solids followed by precipitation by polyethylen glycol and extraction by solvent have been able to reduce sample volumes by about 65-fold without eliminating RT-PCR inhibitors (10). In the present study, a combined method of Casas and Suñén (6) and Haramoto et al. (13) was used for simultaneous concentration of virus particles from liquid and sludge phases of sewage samples. In this adsorption-elution method, virus particles obtain a negative surface charge under neutral $\mathrm{pH}$ and are positively charged under acidic conditions. Therefore, $\mathrm{Al}^{3+}$-coated filters capture the negatively-charged viral particles in neutral $\mathrm{pH}$. The $\mathrm{Al}^{3+}$ cations are then removed via rinsing with $\mathrm{H}_{2} \mathrm{SO}_{4}(\mathrm{pH} 3.0$ ), allowing the positively charged viruses to attach directly to the negatively charged membrane. Finally, elution of viruses with $\mathrm{NaOH}(\mathrm{pH}$ 10.8) takes place (8). Our findings showed that the highest virus count was found in raw sewage samples collected from sampling site 4 (32590 copy number $\mu 1^{-1}$ ) followed by site 6 (28400 copy number $\mu 1^{-1}$ ) and site 1 (14200 copy number $\left.\mu 1^{-1}\right)$. All counts had CT values of $\leq 33$ and were related to the samples collected in cold weather. Only a count of 6500 copy number $\mu 1^{-1}$ with CT value of $\leq 33$ was detected in the treated sewage sample collected from site 6 in cold weather. It should be mentioned that this treatment site was an aerated lagoon, while other sites were based on activated sludge. 
This may indicate that the activated sludge system had been more effective at elimination of HAV in urban sewage, preventing the dissemination of the virus into the environment. This is in line with findings of a study by Prado et al. (21) in Brazil, which found no HAV in treated effluent samples despite the presence of HAV in raw sewage samples. The mentioned study suggested that the viral load could be easily removed by activated sludge treatment of sewage. In the present study, all HAV-positive sewage samples were collected in cold weather. In a study by Sibanda and Okoh (8) in South Africa, $67 \%$ of environmental water samples were found to be positive for HAV during winter months. Chen et al. (22) detected a significant correlation between low water temperatures and incidence of enteroviruses in Damshui River, Taiwan. The level of sewage indicators was increased in cold weather in most sewage samples, and all positive PCR results for HAV genome were detected in cold weather. Mansouri et al. (23) found that $\mathrm{pH}$, $\mathrm{COD}, \mathrm{BOD}_{5}$ and TSS values vary significantly in different seasons. They reported that the maximum rate of COD, BOD5 and TSS removal from final effluents is observed in summer. Moreover, $\mathrm{pH}$ of the effluent decreases in winter compared to summer. In

\section{REFERENCES}

1. Morace G, Aulicino FA, Angelozzi C, Costanzo L, Donadio F, Rapicetta M. Microbial quality of wastewater: detection of hepatitis $A$ virus by reverse transcriptase-polymerase chain reaction. J Appl Microbiol. 2002; 92(5): 828-836.

2. Osuolale $\mathrm{O}$, Okoh A. Incidence of human adenoviruses and Hepatitis A virus in the final effluent of selected wastewater treatment plants in Eastern Cape Province, South Africa. Virol J. 2015; 12: 98. doi: 10.1186/s12985-015-0327-z.

3. Rice EW, Baird RB, Eaton AD. Standard methods for the examination of water and wastewater. $23^{\text {rd }} \mathrm{ed}$, Colorado, American Public Health Association. 2017; 2010-9030.

4. Ryan KJ, Ray CG. Sherris medical microbiology. $4^{\text {th }}$ ed. USA: McGraw Hill. 2004; 541-544.

5. Knipe DM, Howley PM. Fields Fundamental virology. $4^{\text {th }}$ ed. Philadelphia, Lippincott Williams and Wilkins. 2013; 550-580.

6. Casas N, Sunen E. Detection of enteroviruses, hepatitis $A$ virus and rotaviruses in sewage by means of an immunomagnetic capture reverse transcription-PCR assay. Microbiol. Res. 2002; 157(3): 169-75.
China, Song et al. (24) observed that $\mathrm{BOD}_{5}$ and COD removal in wetlands was more efficient in spring and summer than in autumn and winter. The higher efficiency of sewage treatment in warm weather and the predominant prevalence of HAV during winter months (25) could justify the positive results of HAV presence in cold weather.

\section{CONCLUSION}

We detected high frequency of HAV in raw urban sewage samples from Isfahan, Iran. This highlights the importance of paying extra attention to irrigation of farms with raw sewage. Based on the results of this study and previous studies, it can be concluded that the activated sludge system may be more effective for elimination of enteric viruses, such as HAV.

\section{ACKNOWLEDGEMENTS}

This article is derived from an MSc thesis approved (code of 910607180) by the Islamic Azad University, Falavarjan Branch. We appreciate the technical support from the research management of the university.

\section{CONFLICT OF INTEREST}

The authors declare no conflict of interest regarding this manuscript.

7. Chigor VN, Okoh AI. Quantitative RT-PCR detection of hepatitis A virus, rotaviruses and enteroviruses in the Buffalo River and source water dams in the Eastern Cape Province of South Africa. Int J Environ Res Publ Health. 2012; 9(11): 4017-4032.

8. Sibanda T, Okoh AI. Real-time PCR quantitative assessment of hepatitis $A$ virus, rotaviruses and enteroviruses in the Tyume River located in the Eastern Cape Province, South Africa. Water SA. 2013; 39(2): 295-304.

9. Puig M, Jofre J, Lucena F, Allard A, Wadell G, Girones R. Detection of adenoviruses and enteroviruses in polluted waters by nested PCR amplification. Appl Environ Microbiol. 1994; 60(8): 2963-2970.

10. Tsai YL, Tran B, Sangermano LR, Palmer CJ. Detection of poliovirus, hepatitis A virus and rotavirus from sewage and ocean water by triplex reverse transcriptase PCR. Appl Environ Microbiol. 1994; 60(7): 2400-2407.

11. Shieh YSC, Baric RS, Sobsey MD. Detection of low levels of enteric viruses in metropolitan and airplane sewage. Appl Environ Microbiol. 1997; 63(11): 44014407. 
12. Isfahan i. Geography. In: Encyclopedia Iranica. Available

from

http://www.iranicaonline.org/articles/isfahan-i-

geography\#1.

13. Haramoto E, Katayama H, Utagawa E, Ohgaki S. Development of sample storage methods for detecting enteric viruses in environmental water. J Virol Methods. 2008; 151(1): 1-6. doi: 10.1016/j.jviromet.2008.04.006.

14. Costafreda MI, Bosch A, Pinto RM. Development, evaluation, and standardization of a real-time TaqMan reverse transcription-PCR assay for quantification of hepatitis A virus in clinical and shellfish samples. Appl Environ Microbiol. 2006; 72(6): 3846-3855. doi: 10.1128/AEM.02660-05.

15. Lankarani KB, Mahmoodi M, Honarvar B, Nematollahi P, Zamiri N, Ghaffarpasand F. Determinants of poor outcome in patients with hepatitis A infection: a four-year retrospective study in Shiraz, Southern Iran. Arch Virol. 2014; 159(8): 1901-1907.

16. Jacobsen KH, Koopman JS. Declining hepatitis A seroprevalence: a global review and analysis. Epidemiol Infect. 2004; 132(6): 1005-1022.

17. Verhoef L, Boot HJ, Koopmans M, Mollema L, Van Der Klis F, Reimerink J, et al. Changing risk profile of hepatitis $A$ in The Netherlands: a comparison of seroprevalence in 1995-1996 and 2006-2007. Epidemiol Infect. 2011; 139(8): 1172-80. doi: $10.1017 / \mathrm{S} 0950268810003043$.

18. Hoseini S, Kelishadi R, Ataei B, Yaran M, Motlagh M, Ardalan, G, et al. Seroprevalence of hepatitis A in Iranian adolescents: Is it time to introduce a vaccine? Epidemiol Infect. 2016; 144(2): 291-296. doi: $10.1017 /$ S0950268815001302.
19. Glas C, Hotz P, Steffen R. Hepatitis A in workers exposed to sewage: a systematic review. Occup Environ Med. 2001; 58(12): 762-768.

20. Barrimah E, Salem KA, Gabal MS. An outbreak of hepatitis A associated with treated waste water used for irrigation. J Egypt Public Health Assoc. 1999; 74(3-4): 227-39.

21. Prado T, Fumian TM, Miagostovich MP, Gaspar AM. Monitoring the hepatitis A virus in urban wastewater from Rio de Janeiro, Brazil. Trans R Soc Trop Med Hyg. 2012; 106(2): 104-109. doi: 10.1016/j.trstmh.2011.10.005.

22. Chen $\mathrm{CH}$, Hsu BM, Wan MT. Detection of enteroviruses within brackish water from the Damshui River watershed, Taiwan. J Environ Engin. 2008; 134(6): 486.

23. Mansouri B, Ebrahimpour M, Baramaki R. Seasonal differences in treatment efficiency of a set of stabilization ponds in a semi-arid region. Toxicol Environ Chem. 2011; 93(10): 1918-1924.

24. Song Z, Zheng Z, Li J, Sun X, Han X, Wang W, Xu M. Seasonal and annual performance of a full-scale constructed wetland system for sewage treatment in China. Ecol Engin. 2006; 26(3): 272-282.

25. Joon A, Rao P, Shenoy SM, Baliga S. Prevalence of hepatitis A virus (HAV) and hepatitis E virus (HEV) in the patients presenting with acute viral hepatitis. Indian $\mathrm{J}$ Med Microbiol. 2015; 33(5): 102-5. doi: 10.4103/02550857.150908. 